\title{
How to measure separations and angles between intra-molecular fluorescent markers
}

Flyvbjerg, Henrik; Mortensen, Kim; Sung, Jongmin; Spudich, James A.

Published in:

Bulletin of the American Physical Society

Publication date:

2017

Document Version

Early version, also known as pre-print

Link back to DTU Orbit

Citation (APA):

Flyvbjerg, H., Mortensen, K., Sung, J., \& Spudich, J. A. (2017). How to measure separations and angles between intra-molecular fluorescent markers. In Bulletin of the American Physical Society (Vol. Volume 62, Number 4)

\section{General rights}

Copyright and moral rights for the publications made accessible in the public portal are retained by the authors and/or other copyright owners and it is a condition of accessing publications that users recognise and abide by the legal requirements associated with these rights.

- Users may download and print one copy of any publication from the public portal for the purpose of private study or research.

- You may not further distribute the material or use it for any profit-making activity or commercial gain

- You may freely distribute the URL identifying the publication in the public portal

If you believe that this document breaches copyright please contact us providing details, and we will remove access to the work immediately and investigate your claim 


\author{
Abstract Submitted \\ for the MAR17 Meeting of \\ The American Physical Society
}

\begin{abstract}
How to measure separations and angles between intra-molecular fluorescent markers ${ }^{1}$ HENRIK FLYVBJERG, KIM I. MORTENSEN, Tech Univ of Denmark, JONGMIN SUNG ${ }^{2}$, Dept of Biochem and Dept of Phys, Stanford University, JAMES A. SPUDICH, Dept of Biochem, Stanford University School of Medicine - We demonstrate a novel, yet simple tool for the study of structure and function of biomolecules by extending two-colour co-localization microscopy to fluorescent molecules with fixed orientations and in intra-molecular proximity. From each color-separated microscope image in a time-lapse movie and using only simple means, we simultaneously determine both the relative $(\mathrm{x}, \mathrm{y})$-separation of the fluorophores and their individual orientations in space with accuracy and precision. The positions and orientations of two domains of the same molecule are thus timeresolved. Using short double-stranded DNA molecules internally labelled with two fixed fluorophores, we demonstrate the accuracy and precision of our method using the known structure of double-stranded DNA as a benchmark, resolve 10-base-pair differences in fluorophore separations, and determine the unique $3 \mathrm{D}$ orientation of each DNA molecule, thereby establishing short, double-labelled DNA molecules as probes of 3D orientation of anything to which one can attach them firmly.

${ }^{1}$ This work was supported by a Lundbeck fellowship to K.I.M; a Stanford Bio-X fellowship to J.S. and grants from the NIH (GM33289) to J.A.S. and the Human Frontier Science Program (GP0054/2009-C) to J.A.S. and H.F.

${ }^{2}$ Current affiliation: Dept of Biophys, UCSF
\end{abstract}

Henrik Flyvbjerg

Tech Univ of Denmark

Date submitted: 20 Nov 2016

Electronic form version 1.4 